\title{
The legal definition of credit line agreement and its advantages as financing methods
}

\begin{abstract}
Finding financing in any economic state can be challenging, whether you're looking for capital to expand or money to hold on through the tough times. On the other hand, securing such funds is as tough as ever. Due to that, today's economic climate offers different financing methods for the consumer to cover their expenses.

According to banks' daily transactions, the famous ones for customers are credit cards, credit line agreements, and consumer creditslloans. For some authors, the latter one includes both credit cards and credit line agreements. However, all of them have different definitions and requirements for customers.

To differentiate these financing terms helps to certain requirements for each of them and choose the appropriate one for consuming. In this research we will try to find the legal definition of credit line agreements and show their importance in our society.
\end{abstract}

Keywords: credit; credit line agreement; framework agreement; financing methods; loans.

Debts have always existed in human societies. The importance of money as debt has played a dominant part in the emergence of the modern money system and always was a major source of social and personal problems too [6, p. 59]. As a legal category, the essence of credit is always a matter of debate. In modern times, many terms are covered by credit terms. Some academics believe that the loan should be understood in terms of obligations related to the delivery of funds. In the legal literature, credit is accepted as a form of a monetary obligation for the collection and placement of temporarily free funds. A group of researchers believes that credit agreement is a relationship which covers relationships between the amount of cash or certain items that the other party has to lend and the terms set out in the contract. However, in this case, the difference between credit and debt will disappear [5, p. 80].

One of the most common types of lending money in many countries is the credit line. Such agreements are known as "the main loan agreement", "the credit line agreement", "the framework agreement", "the agreement with general terms", "the agreement on open terms" and etc. In Russian civil law, such agreements are referred to as "the framework agreement", "the main agreement", "agreement with open conditions". In German civil law, contracts which are concluded in accordance with the framework agreement must comply with the terms of the main credit line agreement (framework agreement) [1].

The decree of the President of the Republic of Azerbaijan "On ensuring the activity of the Mortgage and Credit Guarantee Fund of the Republic of Azerbaijan" stipulates rules on "Guaran-

\footnotetext{
- Asgarova Fatima Vugar - Master student of the Commercial Law LL.M. Program at Baku State University Law Faculty, Azerbaijan. E-mail: fatima.asgerova@gmail.com
} 
teeing the loans which are taken by entrepreneurs in manat". In these rules, we can differentiate the legal meaning of credit, credit line, and framework agreements. According to the article 2.1.1 of these rules, the framework agreement is a legal document that regulates the interaction of the authorized bank and the Fund in connection with the issuance of a guarantee and (or) interest subsidy. In article 2.1.7 credit is stipulated as the money lent by the authorized bank on the condition of repayment in accordance with the concluded agreement, for a certain period (with the right of extension) and payment of interest (commission). In contrast, credit line agreement is a bank loan that can be used in full or in part in accordance with the loan agreement, of which interest rate is calculated only on the used part of the credit line, and also agreement of which upper limit is set. [2] Another definition for credit line agreement is found on "Rules on the centralized credit register" put into force by The Central Bank of Azerbaijan Republic. In this regulation credit line, agreements are included in credit's itself and do not make a comparison between these provisions [3]. In article 3.1.4 (r) of the same regulation credit also includes loans, credit lines, and credit cards.

However, there was another issue about credit line agreements which solved via interpretation of The Constitutional Court of the Republic of Azerbaijan. There was a tendency among The Supreme Court of the Republic of Azerbaijan and appeal courts about consider credit line agreements as a contract or legal intent of parties. Consequently, the Constitutional Court of the Republic of Azerbaijan decided that a credit line agreement that reflects the parties' will and their mutual rights and obligations should be treated as a contract rather than an agreement of intent [1].

Credit line agreements aim to simplify the convenience of customers and access to financial services. According to such contracts, the bank undertakes to take measures on a credit application in the manner determined by the mutual agreement of the parties at the customer's request. The purpose of the credit line agreement is to organize future civil (economic) relations between the parties. In the line of credit agreement, the parties must clearly define the basic terms and conditions of future contracts. In practice, such terms are defined in a credit line agreement, a credit agreement that is an integral part of it, and a repayment plan. The implementation of credit line agreements is based on international experience and aims to create effective access to financial resources for the banking sector. As a result of opening a credit line, the client will be able to get a loan from the bank as soon as possible, as well as the interest rate arising from the contract will arise after the borrower receives the loan and the amount used.

Positive sides of credit line agreements are stipulated in Turkish legal literature. Credit line agreements are known as "general loan agreements" there and according to different authors, like other contracts, general loan agreements are established with mutual and appropriate declarations of the parties. As one of the most important assignments, it is the method encountered in the application of the banks, which frequently use such loans, prepare general terms of such agreements in advance, unilaterally and independently and do not include credit client's will on the contract. The client has the freedom to always choose another bank or not to use this loan. In this case, it would not be correct to be considered such contracts as which depends on the will of the client [4]. The parties can freely determine the content of the contract they make while making a contract. This is a result of the principle of freedom of contracts. However, this freedom is not unlimited. These agreements cannot be contrary to the mandatory provisions in the law, morality, public order, personal rights, otherwise, they will be considered invalid.

On the other hand, the main element for credit line agreements is their subject matter. If parties agree about the nature of future agreements and main terms of these agreements, then such 
types of agreements are deemed as concluded. According to practice, the main terms of credit line agreements are total loan amount, interest rate, the time limit for pay-back and etc. If parties are agreed in these terms and include it in the agreement, then a credit line agreement will be concluded. Other related agreements only will be part of this agreement and any additions and changes will be forced after making amendments to the main agreement. Mainly, in other contract parties only stipulate money tranches and their repayment time.

Consequently, this research has tried to answer the question of why financing methods are important in our society, what is the main differences among such agreements, and finally, legal meaning and importance of credit line agreements. According to practice no matter to take credit line includes more requirements for consumers, it helps people to get a high amount of loans without waiting and pay the interest rate for the only used amount. Therefore, it is useful to consider the advantages of credit line agreements in comparison with other financing methods. Such agreements need more provisions in legislation to cover all terms and take into account both parties' benefits.

\section{References}

1. Azerbaijan Respublikasi Mulki Mecellesinin 477.0.1-ci maddesinin hemin Mecellenin 470.2ci maddesi ve "Ípoteka haqqinda"Azerbaycan Respublikasi Qanununun 1.0.8 ve 10.5-ci maddeleri, elece de Azerbaycan Respublikasi Mulki Mecellesinin 269.11 ve 307.4-cu maddelerinin "Ípoteka haqqinda"Azerbaycan Respublikasi Qanununun 3.2 ve 10.5-ci maddeleri ile elaqeli shekilde sherh edilmesine dair Azerbaycan Respublikasi Konstitusiya Mehkemesi Plenumunun Qerari [Decision of the Plenum of the Constitutional Court of the public of Azerbaijan on interpretation of Articles 477.0.1 of the Civil Code of the Azerbaijan Republic, Article 470.2 of the same Code and Articles 1.0.8 and 10.5 of the Law of the Republic of Azerbaijan "On Mortgage", as well as Articles 269.11 and 307.4 of the Civil Code of Azerbaijan and Articles 3.2 and 10.5 of the Law of the Republic of Azerbaijan "On Mortgage"]. 31 may 2018, Baku Azerbaijan. Available at: http://www.eqanun.az/framework/39370 (accessed 21.03.2020).

2. "Azerbaycan Respublikasinin Ípoteka ve Kredit Zemanet Fondunun fealiyyetinin temin edilmesi haqqinda" Azerbaycan Respublikasi Prezidentinin 2017-ci il 29 noyabr tarixli Fermaninin 3 nomreli elavesinde nezerde tutulmush "Sahibkarlar terefinden manatla alinan kreditlere teminat verilmesi Qaydasi"["Rules for providing guarantees for loans which are taken by entrepreneurs in manats"stipulated in Appendix No. 3 to the Decree of the President of the Republic of Azerbaijan dated November 29, 2017 "On ensuring the activity of the Mortgage and Credit Guarantee Fund of the Republic of Azerbaijan"]Available at: http://www.e-qanun.az/framework/37056 (accessed 19.03.2020).

3. Azerbaycan Respublikasi Merkezi Bankinin 2013-cü il 11 mart tarixli Qerari ile tesdiq edilmish "Merkezleshdirilmish kredit reyestri haqqinda Qaydalar"["Rules on Centralized Credit Register" approved by the Decision of the Central Bank of the Republic of Azerbaijan dated March 11, 2013]. Available at:http://www.e-qanun.az/framework/11045 (accessed 19.03.2020).

4. "Genel kredi sozlesmeleri" [General loan agreements]. Aksoy Avukatlik Burosu Available at:http://www.aksoyhukuk.com/genel-kredi-sozlesmeleri (accessed 22.03.2020). 
5. Goyusov.R.A. "Kredit ve bank kreditlesmesinin huquqi tebieti ve mahiyyeti" [The legal nature and essence of credits and bank crediting]. Bak1 Universitetinin xeberleri, Sosial-siyasi elmler seriyasi, no. 3, 2012, pp. 80-91.

6. Mellor. M. "The Future of Money: From Financial Crisis to Public Resource". Pluto Press, New York, 2010, 208 p. 
АскароваФ.В.

DOI: 10.25108/2304-1730-1749.iolr.2020.62.15-20

УдК: 346.3

\section{Правовое определение договора кредитной линии и его преимущества как способа финансирования}

Аннотация: Поиск финансирования в любом экономическом государстве может быть непросто, независимо от того, ищете ли вы капитал для расширения или деньги, чтобы продержаться в трудные времена. С другой стороны, обеспечить такие средства так же сложно, как и раньше. В связи с этим современный экономический климат предлагает потребителю различные способы финансирования для покрытия своих расходов.

Согласно ежедневным операциям банков, наиболее известными для клиентов являются кредитные карты, соглашения о кредитных линиях и потребительские кредиты/займы. По мнению некоторых авторов, последнее включает в себя как кредитные карты, так и договоры о кредитных линиях. Однако все они имеют разные определения и требования к клиентам.

Дифференцировать эти условия финансирования помогает наличие определенных требований к каждому из них и выбрать подходящего для потребления. В этих исследованиях мы попытаемся найти юридическое определение соглашений о кредитных линиях и показать их важность в нашем обществе.

Ключевые слова: кредит; договор кредитной линии; рамочное соглашение; методы финансирования; кредиты.

\section{Библиография}

1. Решение Пленума Конституционного Суда общественности Азербайджана о толковании статей 477.0.1 Гражданского кодекса Азербайджанской Республики, статья 470.2 того же Кодекса и статьи 1.0 .8 и 10.5 Закона Азербайджанской Республики “Об ипотеке", а также статьи 269.11 и 307.4 Гражданского кодекса Азербайджанской и статьи 3.2 и 10.5 Закона Азербайджанской Республики “Об ипотеке” [Электронный ресурс] Режим доступа: http://www.e-qanun.az/framework/39370 (дата обращения: 21.03.2020) (на азерб. яз.).

2. "Правила предоставления гарантий по кредитам, которые берут предприниматели в манатах", предусмотренные в Приложении № 3 к Указу Президента Азербайджанской Республики от 29.11.2017., "Об обеспечении деятельности Фонда ипотечных и кредитных гарантий Азербайджанской Республики" [Электронный ресурс] - Режим доступа: http://www.e-qanun.az/framework/37056 (дата обращения: 19.03.2020).

3. Правила централизованного кредитного реестра», утвержденные Решением Центрального банка Азербайджанской Республики от 11 марта 2013 года. [Электронный pecypc] - Режим доступа: http://www.e-qanun.az/framework/11045 (дата обращения:

\footnotetext{
- Аскарова Фатима Вугар кызы - магистр Коммерческого права юридического факультета Бакинского Государственного Университета, Азербайджан. E-mail: fatima.asgerova@gmail.com
} 
19.03.2020) (на азерб. яз.).

4. “Генеральные кредитные соглашения" Адвокатское бюро Аксой [Электронный pecypc] - Режим доступа: http://www.aksoyhukuk.com/genel-kredi-sozlesmeleri(дата обращения: 22.03.2020) (на турец. яз.).

5. Гёюшов Р.А “Сущность и правовая природа кредита и банковского кредитования”// Новости Университета Баку / Серия общественно-политических наук - 2012. - № 3. - С. 8091 (на азерб. яз.).

6. Меллор. М. «Будущее денег: от финансового кризиса к общественным ресурсам». Нью-Йорк: Плутон Пресс, 2010. - 208 с. 